\title{
Ecosystem-Based Management in Fiji: Successes and Challenges after Five Years of Implementation
}

\author{
Stacy D. Jupiter and Daniel P. Egli \\ Wildlife Conservation Society, Fiji Country Program, 11 Ma'afu St, Suva, Fiji \\ Correspondence should be addressed to Stacy D. Jupiter, sjupiter@wcs.org \\ Received 15 June 2010; Accepted 31 August 2010 \\ Academic Editor: Judith D. Lemus
}

Copyright (C) 2011 S. D. Jupiter and D. P. Egli. This is an open access article distributed under the Creative Commons Attribution License, which permits unrestricted use, distribution, and reproduction in any medium, provided the original work is properly cited.

In 2005, a network of 3 large, district-wide marine protected areas (MPAs) and 17 village-managed closures (tabu) was established in Kubulau District, Fiji. Underwater visual census (UVC) data of fish biomass and benthic cover were collected between 2007 and 2009 and analysed with PERMANOVA and ANOSIM to assess differences between closed and open areas. High reef fish biomass (>1000 kg/ha) within closures, significantly elevated over open areas, was consistently observed from: (1) tabu areas on naturally productive reefs within visual distance from villages; and (2) the large, long-term permanent closure located away from fishing pressure. Factors that may have contributed to low fish biomass within closures include small size of closures; noncompliance with management rules; and disclosure of management success to fishers from villages with high reliance on fisheries products. Future success of the network depends on improving awareness of management rules and ensuring implementation within a broader ecosystem framework.

\section{Introduction}

While the tropical western Pacific is a recognized hotspot for global marine biodiversity $[1,2]$, rapid loss of species and stocks are imminent as Pacific Island nations rely heavily on inshore and offshore fisheries for economic development and sustenance [3]. In the Fiji Islands, although fisheries data are often uncertain, there has been a high level of pressure on coastal fisheries in the past few decades [4]. Of the 410 traditionally managed fishing grounds (qoliqoli), at least 70 are considered overexploited while a further 250 are fully developed [5]. Rising prices for fish and fishery products have contributed to declines in artisanal catches from 1996 to 2002 [6], while percentages of catches sold are increasing: catch per unit effort (CPUE) from recent surveys of village catch from locations across Fiji suggests that $>70 \%$ of catch is being sold [7].

In recognition of declines in coastal fisheries and marine biodiversity, there has been a global movement to increase the amount of area in the oceans under some form of protection [8]. The benefits of marine protected areas (MPAs) are recognized to include increases in abundance and biomass of targeted species [9], which may lead to increased recruitment $[10,11]$ and migration of adults into neighbouring areas [12]. These benefits, however, rely strongly on effective compliance and enforcement as well as selection of appropriate size and spacing of MPAs within a network. Furthermore, most positive and lasting effects have been observed in permanent no-take areas compared with partial protection [13] or periodically harvested areas [14].

Over the past two decades, hundreds of communities in the western Pacific have established locally managed marine areas (LMMAs) to control the perceived decline of marine natural resources [15]. The primary tool applied for the management of coastal marine resources within LMMAs is the use of traditional temporary closures, where the local community chooses the location, size, and management regime for their closed area. These areas tend to be small, averaging just $0.2-3.3 \mathrm{~km}^{2}$ for the Cook Islands, Fiji, Papua New Guinea, Samoa, Solomon Islands, and Tonga [15]. Because their boundaries tend to fall within the secure, customary tenure of one village or clan, they are typically easy to manage because there are no overlapping governance constraints and their location is often within visual 
distance from villages [16]. However, while the benefits of many, small reserves can theoretically maximize fisheries yields [17], there may be a threshold size below which potential benefits of protection are outweighed by negative edge effects. Furthermore, the reserves must be placed in appropriate habitat that will maximize fisheries production. There is strong evidence to support reduced fish biomass in habitats characterized by macroalgae and unconsolidated sediments [18], which are typically found on fringing reef flats and backreef lagoons where traditional closures are often established.

In Fiji, an alternative, complementary approach was initiated in Kubulau District in 2005, representing one of the first efforts in Oceania to design and implement an ecologically functional MPA network. Traditional-style periodic closures were combined with large, permanent, notake reserves in a network design using ecosystem-based management $(\mathrm{EBM})$ principles, with approximately 30\% of the qoliqoli area under closure to maximize fisheries and biodiversity benefits [19]. Initial placement of MPAs was based on baseline biological surveys and design criteria which considered size, spacing, and representation of habitats and critical processes (e.g., spawning aggregations) in a multispecies framework $[20,21]$. The design was subsequently modified following extensive socioeconomic assessments and consultations with resource owners in order to spread cost and maximize compliance. An ecosystembased management plan was completed for the protected area network in Kubulau District and qoliqoli [22] and was endorsed by the hierarchy council of chiefs (Bose Vanua) in July 2009. The planning process was informed by extensive scientific and socioeconomic research as well as local and traditional ecological knowledge. Conceptual modeling methods were used to define conservation targets, threats, and management strategies [23] both for the qoliqoli and the adjacent catchments lands in order to embed the MPA network in a broader management framework [24].

This study evaluates the biological and socioeconomic factors that have contributed to the effectiveness of the MPAs within the Kubulau network to achieve their goal of increasing fish biomass following the first five years of management. In particular, we ask (1) which factors are responsible for positive responses of fish populations to management and (2) which factors have contributed to a lack of response in certain cases. Based on the results, we present recommendations for adaptive management of the network to both improve long-term fisheries yields while conserving the unique biodiversity of Kubulau.

\section{Methods}

2.1. Study Region and Management Institutions. Kubulau District, located in Bua Province, Vanua Levu (Fiji), has a population of approximately 1,000 spread between ten villages, seven of which are located on the coast. The catchments of Kubulau district have between 70\%-80\% forest covered with relatively intact hyrodologic connectivity between terrestrial, freshwater, and marine areas [25]. The area of Kubulau's qoliqoli is $260 \mathrm{~km}^{2}$ and its MPA network comprises 17 community-managed MPAs (tabu) sites and 3 district-wide MPAs (Namena, Namuri, Nasue), totalling approximately $80 \mathrm{~km}^{2}$ (Figure 1). Kubulau qoliqoli includes portions of globally significant areas of marine biodiversity [26]. Marine fish diversity estimates from rapid surveys in 2003, including reefs from Kubulau, showed comparable biodiversity to sites in Indonesia and Papua New Guinea [27], while endemic fish represented nearly 5\% of all observed reef fish species in 2009 [28].

While the state maintains ownership of the seabed and overlying waters throughout Fiji, the Fisheries Act explicitly recognizes traditional fishing rights within qoliqoli boundaries by customary land owners [29]. A qoliqoli resource management committee (KRMC) was established in Kubulau in 2005, made up of representatives from each village whose management decisions require authorization from the Bose Vanua. The resource management committee makes broad decisions over regulations for the qoliqoli (including the district MPAs), while village chiefs retain the rights to determine gear restrictions, lifting of temporary closures, and other local regulations in individual village tabu areas [29]. The main management rules for the Kubulau tabu areas and district MPAs evaluated in this study are listed in Table 1.

2.2. Biological Monitoring Surveys. Surveys of fish and benthos were carried out in Kubulau qoliqoli in 2007, 2008, and 2009, with specific methods described below.

2.2.1. Fish Surveys. Underwater visual census (UVC) was carried out at closed and open sites within the qoliqoli to measure fish abundance and size of the following families: Acanthuridae, Balistidae, Carangidae, Carcharhinidae, Chaetodontidae, Ephippidae, Haemulidae, Kyphosidae, Labridae, Lethirinidae, Lutjanidae, Mullidae, Nemipteridae, Pomacanthidae, Scaridae, Scombridae, Serranidae (groupers only), Siganidae, Sphraenidae, and Zanclidae, plus Chanos chanos (Chanidae) as it is a targeted food fish. Surveys were carried out in January 2007, April-May 2008, and April-May 2009 at closed and open sites adjacent to Namena MPA, Namuri MPA, Nasue MPA, Nakali tabu, and Yamotu Lase tabu (2007 and 2008 only), as indicated in Figure 1. Measurements of fish size (total length in $5 \mathrm{~cm}$ size classes for fish less than $40 \mathrm{~cm}$ and exact size over $40 \mathrm{~cm}$ ) and abundance were recorded along five replicate $5 \mathrm{~m} \times 50 \mathrm{~m}$ belt transects at deep $(12-15 \mathrm{~m})$ and shallow depths $(5-8 \mathrm{~m})$ at forereef sites and at reef tops $(0.5-2 \mathrm{~m})$ and shallow depths at backreef sites. A power analysis conducted in late 2008 indicated that changing the sampling design to increased sample size of forereefonly sites would improve the ability to detect differences related to management [28]. As a consequence, only data from forereef sites from datasets prior to 2009 were utilised for all analyses, and only forereef sites were surveyed in 2009.

Observer bias was investigated by assessing the mean number of fish species counted per transect, resulting in the exclusion of data from one observer from Kubulau 2007 surveys (19/346 transects) and data from one observer from Kubulau 2008 surveys (4/391 transects) who routinely counted significantly fewer species than other observers. 

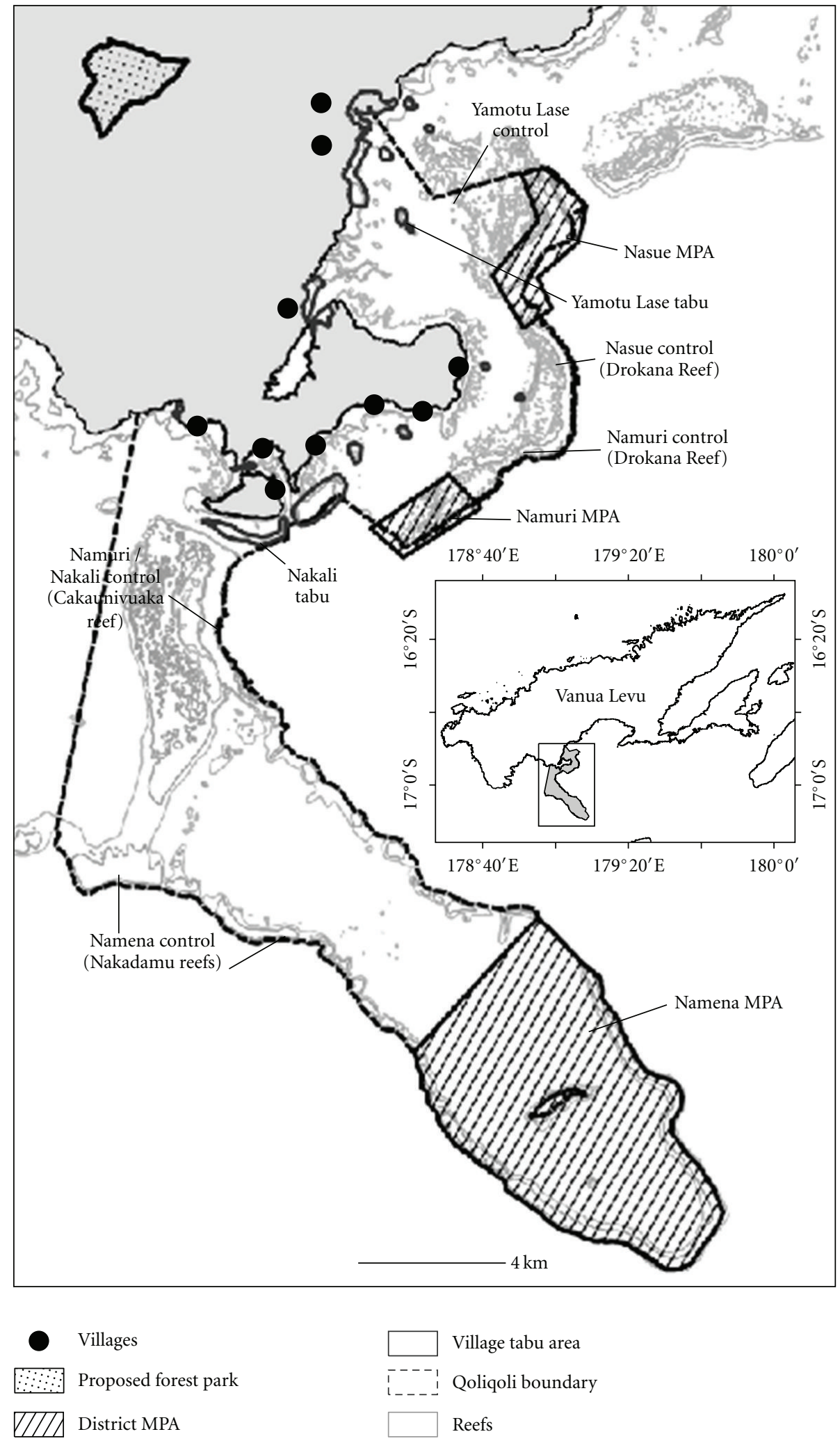

FIGURE 1: Location of MPAs, tabu areas, and adjacent fished areas used as control sites within the Kubulau traditional fishing grounds. Inset map shows the location of Kubulau qoliqoli on Vanua Levu, Fiji. 
TABle 1: List of MPA type, governance, date of establishment, size, and major management rules from the Kubulau Ecosystem-Based Management Plan [22]. KRMC = Kubulau Resource Management Committee.

\begin{tabular}{|c|c|c|c|c|c|}
\hline MPA & Type & $\begin{array}{l}\text { Management } \\
\text { authority }\end{array}$ & Year est. & $\begin{array}{l}\text { Size } \\
\left(\mathrm{km}^{2}\right)\end{array}$ & Major rules \\
\hline & & & & & $\begin{array}{l}\text { (1) Fishing using lines and nets, and diving } \\
\text { for trochus and beche-de-mer is prohibited }\end{array}$ \\
\hline $\begin{array}{l}\text { Yamotu } \\
\text { Lase }\end{array}$ & Tabu & $\begin{array}{l}\text { Village chief } \\
\text { of Nakorovou }\end{array}$ & 2005 & 0.13 & $\begin{array}{l}\text { (2) Use of anchors within the tabu area is } \\
\text { prohibited }\end{array}$ \\
\hline
\end{tabular}

(3) May be opened each year for Saint Teresa feast day, 1 Oct, as authorized by village chief

(4) All other qoliqoli rules apply

(1) Taking any aquatic animal, including fish and beche-de-mer is prohibited

$\begin{array}{clll}\text { Nakali } & \text { Tabu } & \begin{array}{l}\text { Village chief } \\ \text { of Navatu }\end{array} & \text { fish and beche-de-mer is prohibited } \\ & & 0.77 & \text { (2) May only be opened up to three times } \\ & \text { per year, preferably in January, June, and } \\ & \text { November }\end{array}$

(3) All other qoliqoli rules apply

\begin{tabular}{|c|c|c|c|c|c|}
\hline \multirow{3}{*}{ Nasue } & \multirow{3}{*}{$\begin{array}{l}\text { District } \\
\text { MPA }\end{array}$} & \multirow{3}{*}{ KRMC } & \multirow{3}{*}{2005} & \multirow{3}{*}{8.14} & $\begin{array}{l}\text { (1) Taking any aquatic animal, including } \\
\text { fish and beche-de-mer is prohibited }\end{array}$ \\
\hline & & & & & $\begin{array}{l}\text { (2) Use of anchors within the marine reserve } \\
\text { is prohibited, except during authorised } \\
\text { research }\end{array}$ \\
\hline & & & & & (3) All other qoliqoli rules apply \\
\hline \multirow{3}{*}{ Namuri } & \multirow{3}{*}{$\begin{array}{l}\text { District } \\
\text { MPA }\end{array}$} & \multirow{3}{*}{ KRMC } & \multirow{3}{*}{2005} & \multirow{3}{*}{4.25} & $\begin{array}{l}\text { (1) Taking any aquatic animal, including } \\
\text { fish and beche-de-mer is prohibited }\end{array}$ \\
\hline & & & & & $\begin{array}{l}\text { (2) Use of anchors within the marine reserve } \\
\text { is prohibited, except during authorised } \\
\text { research }\end{array}$ \\
\hline & & & & & (3) All other qoliqoli rules apply \\
\hline \multirow{7}{*}{ Namena } & \multirow{7}{*}{$\begin{array}{l}\text { District } \\
\text { MPA }\end{array}$} & \multirow{7}{*}{ KRMC } & \multirow{7}{*}{1997} & \multirow{7}{*}{60.61} & $\begin{array}{l}\text { (1) Taking any aquatic animal, including } \\
\text { fish and beche-de-mer is prohibited }\end{array}$ \\
\hline & & & & & $\begin{array}{l}\text { (2) Removing anything, living or nonliving, } \\
\text { from Namena Reserve is prohibited }\end{array}$ \\
\hline & & & & & $\begin{array}{l}\text { (3) The reserve may only be opened by the } \\
\text { Bose Vanua for the funeral of the Tui } \\
\text { Kubulau or the Tui Nadi }\end{array}$ \\
\hline & & & & & $\begin{array}{l}\text { (4) Diving, snorkeling, or kayaking without } \\
\text { a marine reserve user tag is prohibited }\end{array}$ \\
\hline & & & & & $\begin{array}{l}\text { (5) Marine recreation providers, including } \\
\text { dive operators, must comply with the } \\
\text { Namena Marine Reserve Recreational } \\
\text { Guidelines }\end{array}$ \\
\hline & & & & & $\begin{array}{l}\text { (6) Use of anchors within the marine reserve } \\
\text { is prohibited, except during authorised } \\
\text { research }\end{array}$ \\
\hline & & & & & (7) All other qoliqoli rules apply \\
\hline
\end{tabular}

Biomass was calculated from size class estimates of length (L) and existing published values from Fishbase [30] used in the standard length-weight ( $\mathrm{L}-\mathrm{W})$ expression $\mathrm{W}=a \mathrm{~L}^{b}$, with $a$ and $b$ parameter values preferentially selected from sites closest to Fiji (e.g., New Caledonia). If no L-W parameters were available for the species, the factors for the species with the most similar morphology in the same genus were used [31]. If a suitable similar species could not be determined, averages for the genus were used. As many of the L-W conversions required fork length (FL), a length-length (LL) conversion factor was obtained from Fishbase where necessary to convert from total length (TL) recorded during 
TABLe 2: Maximum published weights from Fishbase [30] applied to listed species sighted above the indicated threshold size.

\begin{tabular}{lcc}
\hline Species & Threshold size $(\mathrm{cm})$ & Max published weight $(\mathrm{kg})$ \\
\hline Trianedon obesus & 180 & 34 \\
Carcharhinus melanopterus & 75 & 13.6 \\
Carcharhinus amblyrhynchos & 150 & 33.7 \\
Chanos chanos & 80 & 14 \\
\hline
\end{tabular}

the surveys to FL before biomass estimation. Because the L$\mathrm{W}$ formula resulted in some grossly overestimated weights for fishes that substantially change morpholog as they age, maximum weights were used for certain species when these fish were sighted above threshold sizes (Table 2).

2.2.2. Benthic Substrate Composition. Benthic life-form categories were recorded along the same $50 \mathrm{~m}$ transects surveyed for fish assemblages at $0.5 \mathrm{~m}$ intervals as described by English et al. [32]. Life-form classes were combined into 6 functional strata: unconsolidated substrate (US: rubble, sand, silt); reef matrix (RM: dead coral, reef pavement, crustose coralline algae, coralline algae); macroalgae (MA: all fleshy macroalgae $>2 \mathrm{~cm}$, including cyanobacteria); live hard coral (LC: including Millepora and Tubipora); other soft substrate (OT: including soft corals, sponges, ascidians, anemones); and turf algae (TA: $\leq 2 \mathrm{~cm}$ height on reef pavement).

2.3. Socioeconomic Surveys. Measures of poaching levels in Kubulau qoliqoli were gauged in two ways. First, in November-December 2008, 51 households were surveyed across 8 villages in Kubulau. Respondents were asked how often they encounter people fishing in breach of MPA rules (regularly, sometimes, rarely, never), and, if they do witness offences, who are the offenders. Secondly, within the four villages (Raviravi, Navatu, Kiobo, Nakorovou) participating in weekly catch per unit effort (CPUE) monitoring between May 2008 and June 2009, fishers were asked to draw on a map the locations where they caught fish. The maps did not show the boundaries of the tabu areas or district MPAs.

2.4. Metrics of Fishing Pressure. Based on the results of the socioeconomic surveys and a literature review, potential surrogates of fishing pressure in Kubulau were assigned for each site, including: proximity to adjacent districts of Wailevu and Wainunu; visibility from Kubulau villages; and distance from Kubulau villages weighted by weekly fish consumption $(\omega)$. The proximities to Wailevu and Wainunu were calculated as the distance $(\mathrm{km})$ from each site to the closest point on either qoliqoli boundary through boat passages using a minimum number of turn points. Distances from villages were measured as the perpendicular distances $(\mathrm{km})$ from each village to the site: this was weighted based on the frequency of fish consumption in each village as assessed from the 2008 household surveys described above where respondents were additionally asked on how many days of the previous week they consumed caught fin fish, based on the formula:

$$
\omega=\frac{\sum_{i}^{N}\left(d_{i} *\left(1 / c_{i}\right)\right)}{N},
$$

where $c$ is the mean number of days per week fish was consumed in the $i$ th village, $d$ is the perpendicular distance from the $i$ th village to the site, and $N$ is the total number of villages $(N=9$ as there was no fish consumption data available for Nasasaivua). All distances were measured in ArcView 3.2a software. Visibility was given a weighted, ranked score as to whether fishers could be spotted from land: 1 = not visible; 6 = can be seen from 1 location or from people walking along coastal fringe; $11=$ can be seen from 2 locations; $16=$ can be seen from $>2$ locations.

2.5. Statistical Analyses. A nonparametric Friedman ANOVA was performed using Statistica version 8 software to assess differences in responses across villages of how often infringements were observed. All other statistical analyses described below were performed in PRIMER version 6 software with PERMANOVA extension [33]. To assess whether fish biomass had increased within the MPAs, PERMANOVA analyses were conducted with 999 permutations using log 10 Modified Gower resemblance matrices of total fish biomass summed at the transect level $[34,35]$. Year and protection status were fixed factors and outputs from within-year results are presented. To assess potential differences in benthic structure that may influence fish community assemblages [18], one-way Analysis of Similarity (ANOSIM) [36] was performed on a similarity matrix calculated with Euclidean distances between square-root transformed mean percent benthic strata cover for each site from 2009 data only, as there was insufficient replication at the site level in 2007 and 2008.

Fish community patterns from the 2009 data were investigated using multidimensional scaling (MDS) plots of a Bray-Curtis resemblance matrix of fish biomass data per species for each site. Data were fourth-root transformed to reduce the influence of large, schooling species, and rare fish species (found at 2 sites or fewer) were removed from the dataset prior to the calculation of the resemblance matrix. Repeated runs of the BVSTEP procedure within BEST were used to identify the most common subset of fish species with the highest correlation $(\geq 0.95)$ to the BrayCurtis similarity matrix for the full suite of species [37]. Significance of the output $\rho_{s}$ statistic was tested using the permutation method of Clarke et al. [38], run over 999 permutations. To evaluate whether the factors likely to affect 


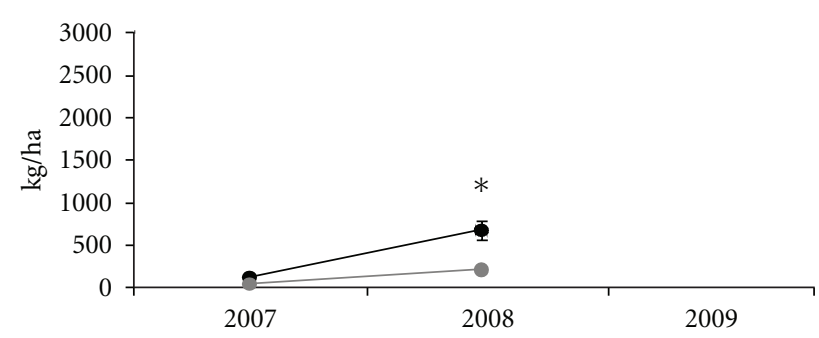

(a) Yamotu Lase

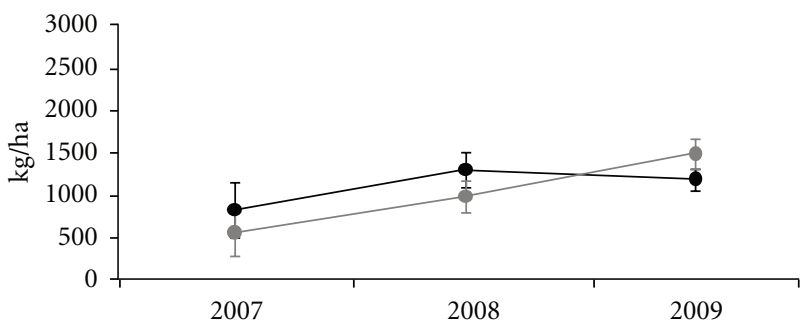

(c) Nasue

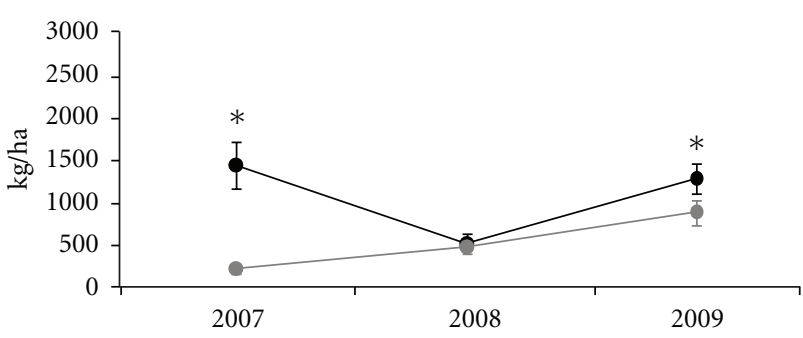

(b) Nakali

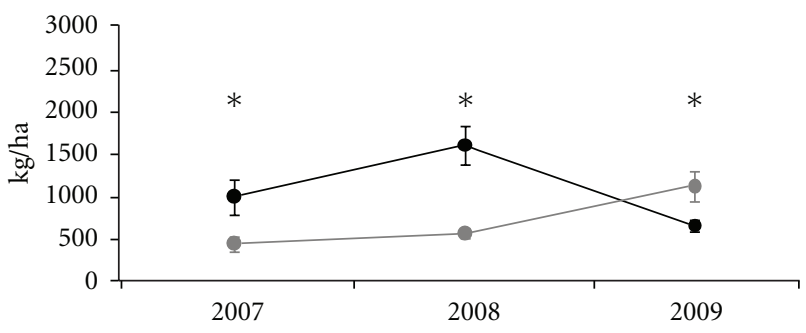

(d) Namuri

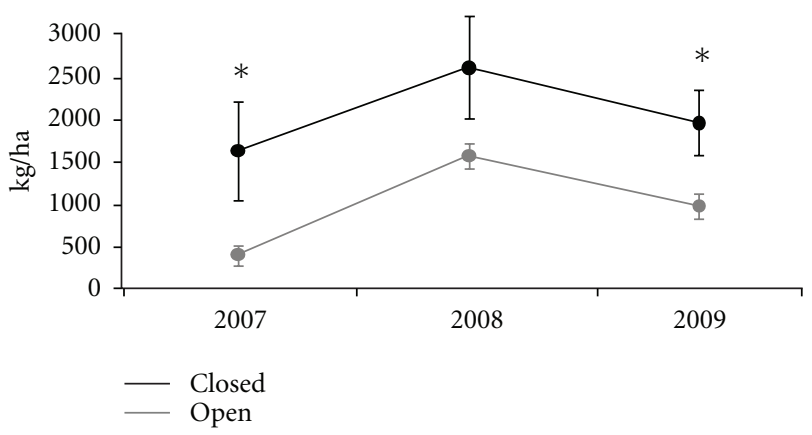

(e) Namena

Figure 2: Mean total fish biomass (kg/ha) in closed (black) and adjacent open (grey) areas of: (a) Yamotu Lase tabu; (b) Nakali tabu; (c) Nasue MPA; (d) Namuri MPA; and (e) Namena MPA for survey periods between 2007 and 2009. Error bars are \pm 1 standard error. $*$ denotes significant difference to at least $P<.05$ with PERMANOVA test.

fishing intensity could explain the patterns in fish biomass structure, a RELATE analysis was conducted to evaluate agreement between the Bray-Curtis resemblance matrix of fish biomass and a resemblance matrix of normalized fishing pressure variables calculated using Euclidean distance [39]. Significance of the output $\rho_{s}$ statistic was tested over 999 permutations.

\section{Results}

Observations of reef fish biomass recovery varied across MPAs. On forereef areas within the village-managed tabu areas, total reef fish biomass was significantly greater than in adjacent fished locations in 2008 only for Yamotu Lase (Figure 2(a) and Table 3(a)) and in 2007 and 2009 (but not 2008) for Nakali (Figure 2(b) and Table 3(b)). Mean total fish biomass was never observed to be significantly higher in the Nasue district MPA than on adjacent fished reefs (Figure 2(c) and Table 3(c)). For the Namuri district MPA, total reef fish biomass was significantly greater within the closed area in 2007 and 2008, but significantly greater in the open areas in 2009 (Figure 2(d) and Table 3(d)). Mean total reef fish biomass was consistently highest from closed sites within the large, offshore Namena district MPA and was significantly greater than open areas on control reefs in 2007 and 2009. Although mean total reef fish biomass inside Namena district MPA was the highest recorded from any reef area in the Kubulau qoliqoli in $2008(2642.73 \mathrm{~kg} / \mathrm{ha})$, the variability across transects $(\mathrm{SE}=601.25 \mathrm{~kg} / \mathrm{ha}$ ) was also the highest observed, mostly due to the presence of large, schooling carangids occurring on some but not all transects.

ANOSIM results comparing benthic composition at the site level showed no overall difference between open and closed sites in the Kubulau qoliqoli (global $R=0.076$; $P=.171$ ). When benthic composition across the 6 major strata was compared between reefs, there were only strong, significant differences between open sites on the Nakadamu reefs used as control for Namena MPA and Cakaunivuaka reef used as control for the Nakali MPA (Table 4), which were not directly compared for fish biomass.

Fish community structure based on species biomass is significantly different $\left(\rho_{s}=0.387 ; P=.001\right)$ from 
TABle 3: PERMANOVA results of differences in fish biomass inside and adjacent to the following MPAs: (a) Yamotu Lase; (b) Nakali; (c) Nause; (d) Namuri; (e) Namena. Mean total fish biomass in closed and open areas is reported in $\mathrm{kg} /$ ha. Significant differences of $P \leq .05$ (derived by permutation analysis) are indicated in bold.

\begin{tabular}{|c|c|c|c|c|}
\hline MPA & Closed & Open & $t$ & $P($ perm $)$ \\
\hline \multicolumn{5}{|c|}{ (a) Yamotu Lase } \\
\hline 2007 & 119.46 & 40.12 & 1.608 & .126 \\
\hline 2008 & 673.64 & 215.36 & 2.633 & .007 \\
\hline \multicolumn{5}{|c|}{ (b) Nakali } \\
\hline 2007 & 1449.71 & 224.64 & 4.639 & .001 \\
\hline 2008 & 521.25 & 485.81 & 0.057 & .953 \\
\hline 2009 & 1296.97 & 897.14 & 2.873 & .006 \\
\hline \multicolumn{5}{|c|}{ (c) Nasue } \\
\hline 2007 & 831.35 & 560.29 & 0.610 & .530 \\
\hline 2008 & 1309.59 & 993.84 & 1.307 & .168 \\
\hline 2009 & 1194.76 & 1498.94 & 1.411 & .187 \\
\hline \multicolumn{5}{|c|}{ (d) Namuri } \\
\hline 2007 & 1015.97 & 461.91 & 2.832 & .008 \\
\hline 2008 & 1625.72 & 585.39 & 5.265 & .001 \\
\hline 2009 & 673.47 & 1143.99 & 2.288 & .025 \\
\hline \multicolumn{5}{|c|}{ (e) Namena } \\
\hline 2007 & 1660.11 & 436.12 & 2.666 & .014 \\
\hline 2008 & 2642.73 & 1602.71 & 1.168 & .243 \\
\hline 2009 & 1994.50 & 1009.31 & 3.004 & .003 \\
\hline
\end{tabular}

TABLE 4: $R$ values from pairwise comparisons from one way ANOSIM of benthic strata across 2009 closed (C) sites within and open (O) sites adjacent to Kubulau MPAs. Significant differences at $P<.05$ are in bold.

\begin{tabular}{lccccccc}
\hline & Namena C & Namena O & Namuri C & Namuri O & Nasue C & Nasue O & Nakali C \\
\hline Namena C & - & & & & & & \\
Namena O & 0.056 & - & - & & & & \\
Namuri C & -0.175 & 0.167 & 0.063 & 0.000 & - & & \\
Namuri O & -0.131 & -0.032 & 0.094 & -0.24 & - & - & - \\
Nasue C & -0.131 & -0.093 & 0.500 & 0.019 & -0.259 & - & \\
Nasue O & 0.077 & 0.155 & 0.448 & 0.063 & 0.135 & 0.074 & -0.056 \\
Nakali C & 0.206 & $\mathbf{0 . 3 8 3}$ & 0.463 & -0.019 & 0.074 & 0.407 & \\
Nakali O & 0.190 & & & & & & \\
\hline
\end{tabular}

the underlying structure that would have been predicted from the surrogate measures of fishing pressure alone (Figure 3). The protected Namena MPA sites, which are distant from Kubulau villages and adjacent districts, are in general agreement with the fishing pressure model in that they are more distant from the majority of other sites in both MDS plots in Figure 3. However, the Nakali tabu fish communities, which responded strongly to management in 2009, clustered more closely with the Namena closed sites, despite the fact that Nakali is located close to Wainunu District and to Kubulau villages that consume a lot of fish. The position of Namena and Nakali closed sites in Figure 3(a) is best explained by high biomass of fusiliers (e.g., Pterocaesio pisang), important food fish such as Naso unicornis, N. vlamingii, Caranx melampygus, Plectorhinchus chaetodonoides, and Lutjanus fulviflamma, and important reef cleaners such as Scarus niger and Chlorurus bleekeri.
The position of the other more clustered sites from Nasue, Drokana, Namuri, and Cakaunivuaka is best explained by high biomass of schooling and solitary grazers: Ctenochaetus striatus, Siganus doliatus, S. uspi, Chlorurus sordidus, and Scarus schlegeli, with secondary or no importance as food fish.

There were no significant differences between villages in response to how frequently the respondents observed infringements of MPA rules in the Kubulau qoliqoli (Friedman's ANOVA: $\chi_{4,7}^{2}=5.833 ; P=.559$ ), with most respondents reporting that they sometimes or rarely witnessed offences. Of the 33 respondents who answered the question of who was committing offences, $75.8 \%(n=25)$ replied that they were nonresource rights owners coming from outside the Kubulau qoliqoli. Only 9.1\% $(n=3)$ reported that the offenders came exclusively from within Kubulau; however notably, only 2 of the 8 residents of Navatu village responded 


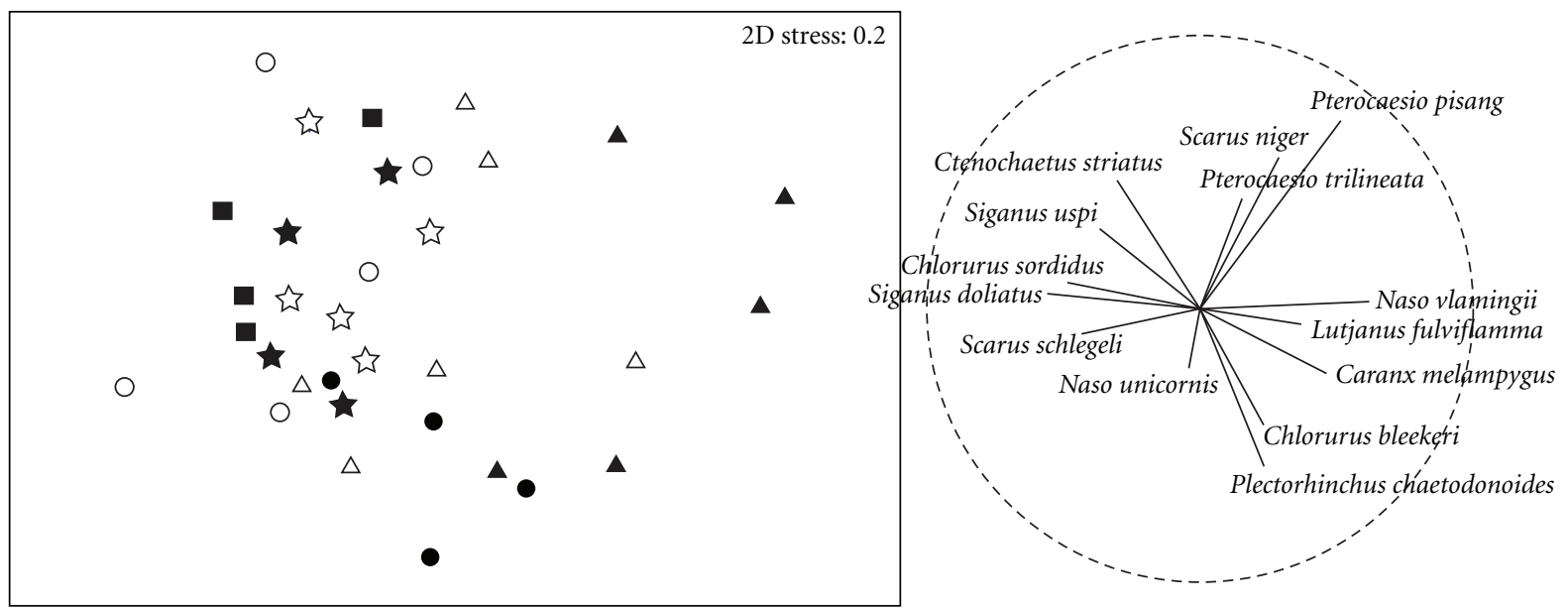

(a)
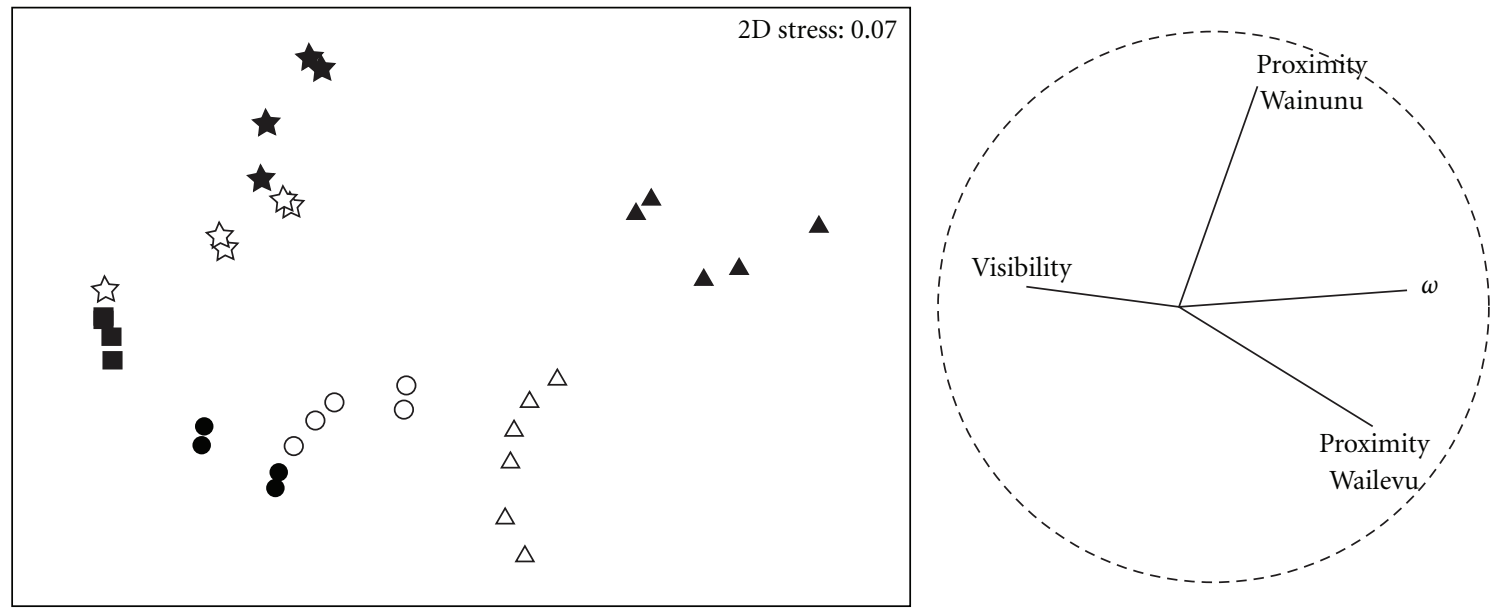

- Nakali tabu
- Nasue MPA
- Namuri MPA
- Namena MPA

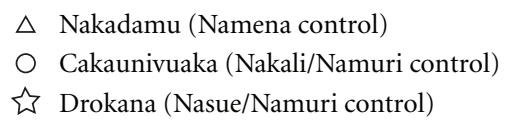

(b)

Figure 3: MDS plots showing distances between sites for (a) mean fish species biomass, coupled with vector trajectories for fish species that best explained variation among sites; and (b) potential fishing pressure, coupled with vector trajectories for all fishing pressure surrogates. Dark circles = Nakali tabu; open circles = Nakali/Namuri control (Cakaunivuaka reef); dark stars = Nasue MPA; open stars = Nasue/Namuri control (Drokana reef); dark square = Namuri MPA; dark triangle = Namena MPA; open triangle = Namena control $($ Nakadamu reefs $)$.

to this question: Navatu residents have been repeatedly caught fishing within the Namena MPA. Synthesis of catch locations from CPUE surveys showed multiple instances of fishing activity from within MPA boundaries by local Kubulau fishers, in particular within: Nasue district MPA; Namuri district MPA; Yamotu ni Oqo, Bovici and Bagata (Kilaka's village tabus); and Rewa Bota, Yamotu Lase and Yamotu Vutia (Nakorovou's village tabus; Figure 4).

\section{Discussion}

Many different factors can potentially influence whether or not MPAs and MPA networks are effective in reaching their conservation and management goals. These factors can include, but are not limited to: degree of protection (permanent no-take, periodic opening, partial closures); awareness of and degree of compliance with MPA rules; visibility from land; design of MPAs and MPA networks; benthic habitat condition; frequency and intensity of current and historical disturbance (e.g., land-based pollution, bleaching, tropical cyclones, crown-of-thorns outbreaks); and longevity of protection $[9,16,18,19]$. As the goals of the Kubulau tabus and MPAs were primarily to increase size and abundance of food fish, we evaluate the results of our surveys in the context of the above factors to determine where management has been effective and where there needs to be improvements. 


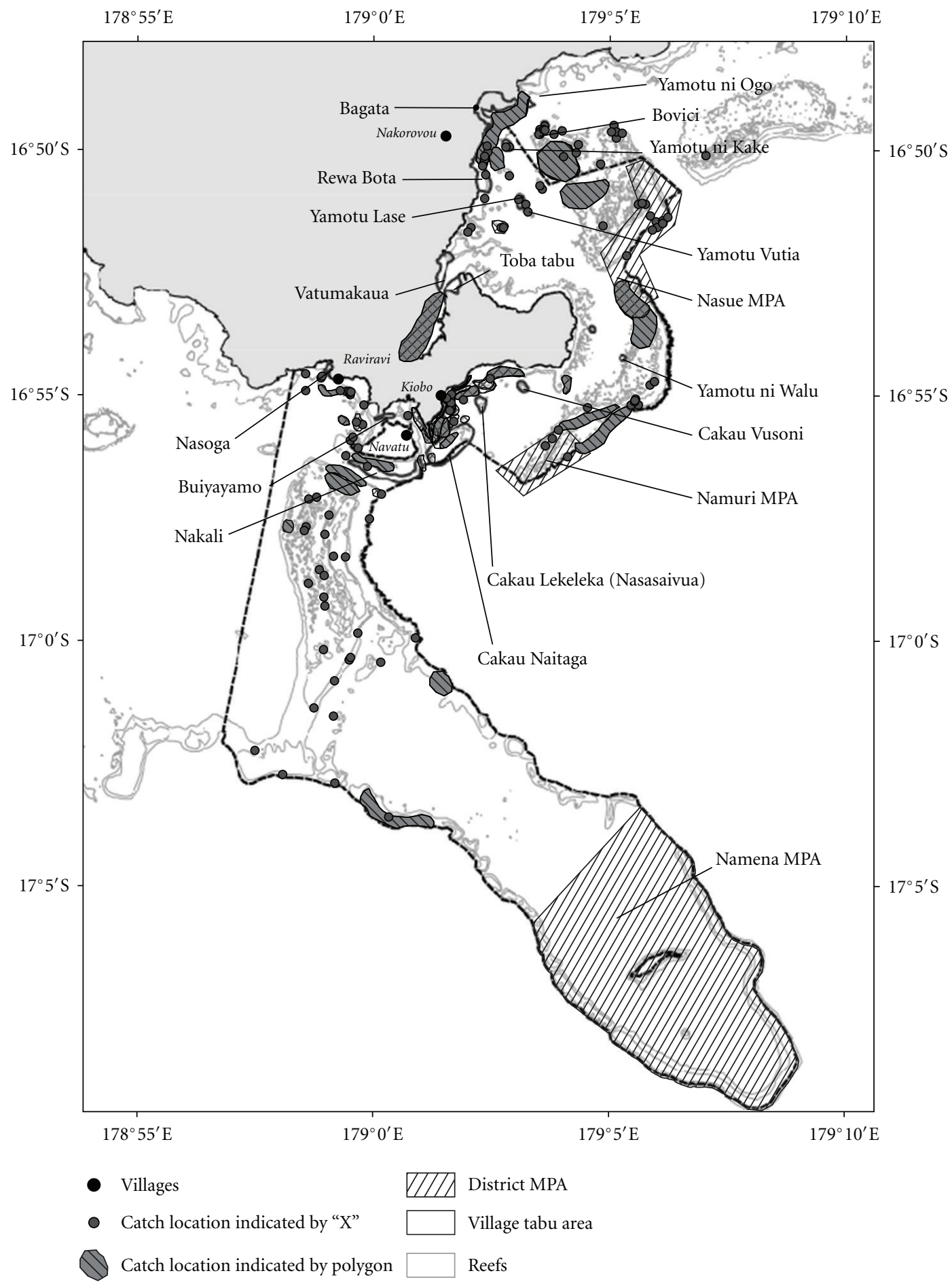

FIGURE 4: Fishing locations (grey circles and shaded grey polygons) recorded by Kubulau fishers from Raviravi, Navatu, Kiobo, and Nakorovou fishers between May 2008 and June 2009. CPUE locations, District MPAs, and tabu areas are labelled.

We additionally discuss how the MPA network can be adaptively managed within an EBM framework to respond to these improvements.

4.1. Small, Village-Managed MPAs. Monitoring the effectiveness of the small tabus has been challenging, largely because they may be too small to fit well-replicated survey sites within their boundaries (e.g., Bartlett et al. [40]), thus preventing rigorous statistical analysis. For example, only 1 survey site with 5 replicate transects could be placed inside the Yamotu Lase tabu $\left(0.13 \mathrm{~km}^{2}\right)$ without the risk of pseudoreplication. Even with this low statistical power, 2008 data indicate 
TABle 5: Comparison of mean fish biomass ( $\mathrm{kg} / \mathrm{ha}$ ) evaluated from underwater visual census (UVC) at protected and fished sites in the Indo-Pacific.

\begin{tabular}{|c|c|c|c|}
\hline Location & Fish group & $\begin{array}{l}\text { Mean Biomass } \\
\text { range }(\mathrm{kg} / \mathrm{ha})\end{array}$ & Source \\
\hline $\begin{array}{l}\text { Kubulau, } \\
\text { Fiji (Namena) }\end{array}$ & $\begin{array}{l}\text { Total fish protected } \\
\text { Total fish open }\end{array}$ & $\begin{array}{l}1647-2633 \\
1009-1758 \\
\end{array}$ & This study \\
\hline $\begin{array}{l}\text { Kubulau, } \\
\text { Fiji (Namuri/Nasue) }\end{array}$ & $\begin{array}{l}\text { Total fish protected } \\
\text { Total fish open }\end{array}$ & $\begin{array}{l}673-1626 \\
462-1499 \\
\end{array}$ & This study \\
\hline $\begin{array}{l}\text { Kubulau, } \\
\text { Fiji (Yamotu Lase) }\end{array}$ & $\begin{array}{l}\text { Total fish protected } \\
\text { Total fish open }\end{array}$ & $\begin{array}{c}119-674 \\
40-215 \\
\end{array}$ & This study \\
\hline Vatu-i-Ra, Fiji & Total fish & $\sim 550-900$ & {$[27]$} \\
\hline $\begin{array}{l}\text { Northern Lagoon, } \\
\text { New Caledonia }\end{array}$ & $\begin{array}{l}\text { Targeted fish along } \\
\text { terrestrial gradients }\end{array}$ & $148-447$ & {$[44]$} \\
\hline $\begin{array}{l}\text { North Efate, } \\
\text { Vanuatu }\end{array}$ & $\begin{array}{l}\text { Vulnerable fish protected } \\
\text { Vulnerable fish open } \\
\text { Less vulnerable fish protected } \\
\text { Less vulnerable fish open }\end{array}$ & $\begin{array}{l}508-669 \\
175-296 \\
307-381 \\
261-302\end{array}$ & {$[40]$} \\
\hline $\begin{array}{l}\text { Ahus Island, Papua } \\
\text { New Guinea }\end{array}$ & $\begin{array}{l}\text { Total fish protected } \\
\text { Total fish open }\end{array}$ & $\begin{array}{l}\sim 225 \\
\sim 120\end{array}$ & {$[45]$} \\
\hline $\begin{array}{l}\text { Muluk, Papua New } \\
\text { Guinea }\end{array}$ & $\begin{array}{l}\text { Targeted fish protected } \\
\text { Targeted fish open }\end{array}$ & $\begin{array}{l}378 \\
301 \\
\end{array}$ & {$[41]$} \\
\hline $\begin{array}{l}\text { Karkarotan, } \\
\text { Indonesia }\end{array}$ & $\begin{array}{l}\text { Targeted fish protected } \\
\text { Targeted fish open }\end{array}$ & $\begin{array}{l}139 \\
101 \\
\end{array}$ & {$[41]$} \\
\hline $\begin{array}{l}\text { Apo Island, } \\
\text { Philippines }\end{array}$ & $\begin{array}{l}\text { Targeted fish protected } \\
\text { Targeted fish open }\end{array}$ & $\begin{array}{l}\sim 250-1200 \\
\lesssim 100-850\end{array}$ & {$[14]$} \\
\hline $\begin{array}{l}\text { Line Islands, } \\
\text { Kiribati and USA }\end{array}$ & $\begin{array}{l}\text { Total fish along human } \\
\text { impact gradient }\end{array}$ & $1300-5300$ & {$[46]$} \\
\hline
\end{tabular}

positive significant differences in total reef fish biomass compared to adjacent fished areas. Further examination of the data from 2008 shows that although the ranges of total fish biomass in the small, community-managed tabu of Yamotu Lase are comparable to the ranges reported for the small periodically closed areas on inshore, fringing reefs adjacent to Muluk village of PNG [41], Karkarotan village of Indonesia [41] and in Efate, Vanuatu [40] (Table 5), overall mean biomass is low compared with both fished and some unfished barrier reef areas in Kubulau qoliqoli. Secondly, the mean biomass of fish primarily targeted for consumption comprised only $21.6 \%$ of the total biomass recorded within the tabu, which is a substantially lower percentage than in the Namena MPA where primary targets comprised $72.0 \%$ of the total fish biomass. The low values for primary food fish may be due to the fact that the management rules for Yamotu Lase include a provision for an annual harvest for the feast of Saint Theresa (Table 1) and that local fishers have themselves reported fishing inside the MPA (Figure 4). Repeated harvests and sustained fishing pressure may reduce the size structure of fishing communities, resulting in fewer, smaller individuals [42, 43].

The Nakali tabu, while also small $\left(0.77 \mathrm{~km}^{2}\right)$, supported over ten times the total fish biomass as the Yamotu Lase tabu in 2007. This is likely due to the natural geomorphology of the reef system in which the offshore barrier is located within $1 \mathrm{~km}$ from land and is regularly flushed with high currents through the Naisonisoni Passage. High currents along reef walls provide important fluxes of zooplankton, upon which planktivorous fish feed [47], some of which (e.g., schooling damselfish) are prey for larger-bodied carnivores. The currents may also bring nutrients supporting algal growth upon which large herbivores (e.g., Naso unicornis) feed. N. unicornis are preferred food fish of many Fijian fishers and were sighted in large numbers and sizes at all sites within Nakali. By 2008, however, sites in Nakali no longer supported greater biomass than adjacent fished areas and there was significantly more fish outside the MPA. This is most likely because the village of Navatu harvested the tabu three times between survey periods, which is within the community-declared management provisions of the Nakali tabu (Table 1). Despite the high frequency of harvests, the natural features of the reef may be highly resilient to exploitation as reef fish populations, in particular of primary food fish, had recovered substantially by 2009. In addition, the close proximity of the tabu to Navatu village facilitates compliance as offenders would be visible from shore.

Given the strong community buy-in across Fiji to the establishment and maintenance of small tabu areas [15], it is important to maintain the cultural traditions that support the management of existing small tabu areas and the establishment of new sites. However, management support networks like the Fiji LMMA network would do well to increase awareness among community members of the potential consequences of harvesting to ensure that periodic openings of tabus are done in a limited and controlled 
manner only according to provisions in management plans. Further, when establishing new sites for tabu placement, conservation partners should aid communities to select the most naturally productive and resilient areas where possible, which can be identified using the methodologies of Green and Bellwood [48] and Obura and Grimsditch [49].

4.2. Large, District-Managed MPAs. The results from the larger MPAs located $<10 \mathrm{~km}$ offshore (Nasue, Namuri) in Kubulau are equivocal. For example, total fish biomass inside Nasue MPA was never significantly greater than on adjacent fished reefs. The MPA is located relatively close to the mouth of the Yanawai River, which in the past has discharged runoff from the upstream Mt. Kasi gold mine. However, the mine is no longer operational and there did not appear to be any significant difference in benthic composition from sites inside and adjacent to the MPA, suggesting little current terrestrial influence [50]. Based on the responses from perceptions surveys in Kubulau, external poaching from the adjacent Wailevu District is likely to play a critical role in influencing the total fish biomass and species composition within the MPA. The Nasue MPA shares a boundary with the neighbouring Wailevu qoliqoli, and Wailevu fishers have been repeatedly caught fishing in the MPA, a problem compounded by the fact that the MPA is not visible from any of the villages in Kubulau. External poaching has been a common occurrence across sites within the FLMMA network when adjacent communities hear about local management success. The heavy fishing pressure has affected fish community structure by removing important food fish, leaving the reefs dominated by opportunistic grazers (e.g., Ctenochaetus striatus, Chlorurus sordidus) and nontargeted species. In order to combat this problem, the Kubulau Bose Vanua and KRMC have resolved to stage meetings with their neighbours from both Wailevu and Wainunu to both raise awareness of the management rules in the Kubulau EBM plan and to assist the districts to establish their own protected area networks and management rules.

The Namuri MPA appeared to be effectively protecting marine resources in 2007 and 2008, with significantly higher total fish biomass inside compared with adjacent fished areas. The opposite pattern was observed from 2009 surveys, provoking some concern that when Kubulau fishers were made aware of the exceptionally high biomass inside Namuri MPA during a management planning workshop in February 2009, they may have proceeded to covertly fish the area. Indeed, the monitoring sites within Namuri all had exceptionally low consumption-weighted distance-tovillage scores $(\omega)$, indicating that they are near numerous villages whose residents frequently consume fish and would therefore be susceptible to high levels of fishing intensity without management (Figure 3(b)) or if management rules were ignored. Thus, in an attempt to use the monitoring data to foster discussions related to management implementation, its public presentation may have had detrimental consequences for the fishery [51]. To resolve these issues, more careful attention needs to be paid with respect to dissemination of sensitive monitoring information which in the future should likely only be shared during restricted meetings with the KRMC and Bose Vanua.

The Namena MPA demonstrated the strongest results in terms of increasing food fish biomass. The upper range of mean total fish biomass observed in Namena $(2643 \mathrm{~kg} / \mathrm{ha}$; Table 3(e)) falls within the range of values reported for Palmyra atoll in the northern Line Islands, which is considered to have relatively intact trophic structures and minimal impact from humans (Table 5) [46]. The Namena MPA has been informally established as a permanent no-take protected area since 1997, when the high council of chiefs both banned commercial fishing from the qoliqoli and set up the reserve around the reefs of Namenalala Island [29]. The longevity and permanence of the closure has enabled recovery of large-bodied piscivores such as carangids, serranids, and lutjanids, which have low growth and recruitment rates and are highly vulnerable to overfishing [52]. Increases in biomass of these taxa from growth alone may take a decade to observe, as opposed to biomass increases from successful adult fish attraction following the closure of an MPA, which can occur rapidly over 1-3 years [53-55]. At $60.6 \mathrm{~km}^{2}$, Namena is the largest MPA in Fiji, covering an extensive barrier reef system that extends outward into the deep waters of the Vatu-i-Ra passage. High currents flush the reef, supporting an abundance of top predators, including schools of hammerhead sharks which draw dive tourists from around the globe. Like in the Nakali tabu, these naturally favourable habitats may promote rapid recovery of exploited populations [21].

Given that there is international dive tourism in Namena which brings revenue to the communities of Kubulau through the payment of user fees to dive in the MPA, there is high incentive from the communities to enforce the MPA regulations. The chiefs of Kubulau have empowered the owners of Moody's Namena Resort, located within the reserve, to patrol the area, and trained community fish wardens may board vessels suspected of illegal fishing activity [29]. Due to this vigilance, there is unlikely to be poaching for subsistence fishing from fishers coming from the mainland given the high price of boat fuel: fishers would only be attracted to the area if they have guaranteed access to a market to sell their catch. While villagers say that this still remains a potential problem, the extent of illegal fish extraction for sale prior to surveys in 2009 did not appear to be overly compromising the biological effectiveness of Namena.

\section{Conclusion}

In the Kubulau MPA network, the factors which appear to have the most influence on the success of management to provide protection of exploited species included: size; placement of reserves in naturally productive habitats; visibility from land; distance from potential poachers; degree and longevity of protection. Some key recommendations to improve and expand MPA networks to other sites in Fiji include the following.

(i) MPAs need to be larger than the home ranges of targeted fish species. Recent fish tagging studies from 
the Coral Coast of Fiji have shown that Lethrinus spp. can move up to $700 \mathrm{~m}$ and do so mostly at night [56]. Therefore, MPAs should be at least double this length on both sides in order to ensure that fish are not caught while foraging.

(ii) Though some studies have observed limited increases in fish biomass and abundance despite periodic opening $[40,41]$, the ability of fish populations to recover from harvests is likely to depend both on the frequency and intensity of harvest events [57]. Permanently closed areas provide the maximum level of protection and degree of recovery. Russ and Alcala [58] make a strong argument for permanent closures as a precautionary principle because the "benefits accrue slowly but are lost quickly" with repeated fishing events.

(iii) MPA placement can enhance success when factors such as natural geomorphology and oceanographic features of the region promote rapid recovery. Placement in high visibility areas can also promote compliance, though visibility need not always imply that they be placed within direct sight of villages. Visibility can be improved by frequent enforcement patrols, though resourcing is required for boats and fuel. Resource management committees must therefore place priority on financing enforcement activities through their varied sources of revenue.

(iv) Lastly, management of MPAs cannot occur in isolation of potential disturbance from outside the fisheries management areas (e.g., from land-based threats or commercial fisheries operating in adjacent, connected areas). MPA management needs to be placed into the context of a broader ecosystem framework in order to reduce local threats to reef systems and therefore improve resilience [24]. Within Kubulau and across Fiji, EBM requires close collaboration between upland and lowland villages as well as engagement of stakeholders across multiple sectors, including fisheries, forestry, agriculture, tourism, and cultural heritage.

\section{Acknowledgments}

This study was supported by grants from the David and Lucile Packard Foundation (2007-31847), the Gordon and Betty Moore Foundation (540.01), and the US National Oceanic and Atmospheric Administration (NA07NOS4630035). The authors gratefully acknowledge the support of the chiefs and communities of Kubulau, the volunteers, and the staff who assisted with field surveys, management planning, and data analysis: D. Blaik, A. Cakacaka, A. Caginitoba, S. Dulunaqio, S. Fitzpatrick, F. Hartley, S. Ledua, U. Mara, W. Moy, A. Murphy, W. Naisilisili, Y. Nand, A. Patrick, S. Prasad, I. Qauqau, W. Saludrau, L. Sivo, T. Tui, P. Veileqe, H. Williams, and N. Yakub. The authors are grateful to D. Olson, L. Farley, K. Tabunakawai, and A. Jenkins, who initially conceived the project, and to K. Walls and M. Callow for project management support.

\section{References}

[1] T. P. Hughes, D. R. Bellwood, and S. R. Connolly, "Biodiversity hotspots, centres of endemicity, and the conservation of coral reefs," Ecology Letters, vol. 5, no. 6, pp. 775-784, 2002.

[2] C. M. Roberts, C. J. McClean, J. E. N. Veron et al., "Marine biodiversity hotspots and conservation priorities for tropical reefs," Science, vol. 295, no. 5558, pp. 1280-1284, 2002.

[3] R. Gillett, Fisheries in the Economies of Pacific Island Countries and Territories, Asian Development Bank, Mandaluyong City, Philippines, 2009.

[4] L. C. L. Teh, L. S. L. Teh, B. Starkhouse, and U. Rashid Sumaila, "An overview of socio-economic and ecological perspectives of Fiji's inshore reef fisheries," Marine Policy, vol. 33, no. 5, pp. 807-817, 2009.

[5] T. Hand, D. Davis, and R. Gillett, Fisheries Sector Review: Republic of the Fiji Islands, Asian Development Bank, Mandaluyong City, Philippines, 2005.

[6] J. Raj and N. Evans, "The role of trade in fisheries production and consumption in Fiji. Background paper," in Proceedings of the Pacific Islands Regional Ocean Forum, Suva, Fiji, 2004.

[7] Institute of Applied Sciences (IAS), "A nation-wide survey of village-based fishing pressure in Fiji," in Proceedings of the Inaugural Fiji Islands Conservation Science Forum, A. P. Jenkins, S. R. Prasad, J. Bacchiochi, P. Skelton, and N. Yakub, Eds., Wetlands International-Oceania, Suva, Fiji, 2009.

[8] IUCN, Accelerating Progress to Establish Marine Protected Areas and Creating Marine Protected Area Networks, The World Conservation Union, Gland, Switzerland, 2009.

[9] S. E. Lester, B. S. Halpern, K. Grorud-Colvert et al., "Biological effects within no-take marine reserves: a global synthesis," Marine Ecology Progress Series, vol. 384, pp. 33-46, 2009.

[10] I. Tetreault and R. F. Ambrose, "Temperate marine reserves enhance targeted but not untargeted fishes in multiple no-take MPAS," Ecological Applications, vol. 17, no. 8, pp. 2251-2267, 2007.

[11] R. D. Evans, G. R. Russ, and J. P. Kritzer, "Batch fecundity of Lutjanus carponotatus (Lutjanidae) and implications of notake marine reserves on the Great Barrier Reef, Australia," Coral Reefs, vol. 27, no. 1, pp. 179-189, 2008.

[12] G. R. Russ and A. C. Alcala, "Do marine reserves export adult fish biomass? Evidence from Apo Island, central Philippines," Marine Ecology Progress Series, vol. 132, no. 1-3, pp. 1-9, 1996.

[13] C. M. Denny and R. C. Babcock, "Do partial marine reserves protect reef fish assemblages?” Biological Conservation, vol. 116, no. 1, pp. 119-129, 2004.

[14] A. C. Alcala, G. R. Russ, A. P. Maypa, and H. P. Calumpong, "A long-term, spatially replicated experimental test of the effect of marine reserves on local fish yields," Canadian Journal of Fisheries and Aquatic Sciences, vol. 62, no. 1, pp. 98-108, 2005.

[15] H. Govan, A. Tawake, K. Tabunakawai et al., Status and Potential of Locally-Managed Marine Areas in the South Pacific: Meeting Nature Conservation and Sustainable Livelihood Targets through Wide-Spread Implementation of LMMAs, SPREP/WWF/WorldFish-Reefbase/CRISP, Suva, Fiji, 2009.

[16] S. Aswani and R. Hamilton, "The value of many small vs. few large marine protected areas in the Western Solomon Islands," SPC Traditional Marine Resource Management and Knowledge Information Bulletin, vol. 16, pp. 3-14, 2004.

[17] A. Hastings and L. W. Botsford, "Comparing designs of marine reserves for fisheries and for biodiversity," Ecological Applications, vol. 13, no. 1, pp. S65-S70, 2003. 
[18] A. M. Friedlander, E. K. Brown, and M. E. Monaco, "Coupling ecology and GIS to evaluate efficacy of marine protected areas in Hawaii," Ecological Applications, vol. 17, no. 3, pp. 715-730, 2007.

[19] S. D. Gaines, C. White, M. H. Carr, and S. R. Palumbi, "Designing marine reserve networks for both conservation and fisheries management," Proceedings of the National Academy of Sciences, 2010.

[20] G. R. Almany, S. R. Connolly, D. D. Heath et al., "Connectivity, biodiversity conservation and the design of marine reserve networks for coral reefs," Coral Reefs, vol. 28, no. 2, pp. 339$351,2009$.

[21] E. McLeod, R. Salm, A. Green, and J. Almany, "Designing marine protected area networks to address the impacts of climate change," Frontiers in Ecology and the Environment, vol. 7, no. 7, pp. 362-370, 2009.

[22] WCS, Ecosystem-Based Management Plan: Kubulau District, Vanua Levu, Fiji, Wildlife Conservation Society, Suva, Fiji, 2009.

[23] N. Salafsky and R. Margoluis, "Threat reduction assessment: a practical and cost-effective approach to evaluating conservation and development projects," Conservation Biology, vol. 13, no. 4, pp. 830-841, 1999.

[24] B. S. Halpern, S. E. Lester, and K. L. McLeod, "Placing marine protected areas onto the ecosystem-based management seascape," Proceedings of the National Academy of Sciences, 2010.

[25] A. P. Jenkins, S. D. Jupiter, I. Qauqau, and J. Atherton, “The importance of ecosystem-based management for conserving aquatic migratory pathways on tropical high islands: a case study from Fiji," Aquatic Conservation: Marine and Freshwater Ecosystems, vol. 20, no. 2, pp. 224-238, 2010.

[26] World Wildlife Fund (WWF), Setting Priorities for Marine Conservation in the Fiji Islands Marine Ecoregion, WWF South Pacific Programme, Suva, Fiji, 2004.

[27] M. Marnane, G. Allen, L. Farley, L. Sivo, and S. Dulunaqio, Scientific Report on an Expedition to the Vatu-i-Ra/Lomaiviti Passage, Wildlife Conservation Society, Suva, Fiji, 2003.

[28] S. D. Jupiter, D. P. Egli, A. P. Jenkins et al., "Effectiveness of marine protected area networks in traditional fishing grounds of Vanua Levu, Fiji, for management of sustainable inshore fisheries," Wetlands International-Oceania Technical Report 03/10, Wildlife Conservation Society-Fiji, Suva, Fiji, 2010.

[29] P. Clarke and S. D. Jupiter, "Law, custom and communitybased natural resource management in Kubulau District (Fiji)," Environmental Conservation, vol. 37, pp. 98-106, 2010.

[30] R. Froese and D. Pauly, FishBase, World Wide Web Electronic, 2009, http://www.fishbase.org/.

[31] S. Jennings and N. V. C. Polunin, "Effects of fishing effort and catch rate upon the structure and biomass of Fijian reef fish communities," Journal of Applied Ecology, vol. 33, no. 2, pp. 400-412, 1996.

[32] S. English, C. Wilkinson, and V. Baker, Survey Manual for Tropical Marine Resources, Australian Institute of Marine Science, Townsville, Australia, 1997.

[33] K. R. Clarke and R. N. Gorley, PRIMER v6: User Manual/Tutorial, PRIMER-E, Plymouth, UK, 2006.

[34] B. H. McArdle and M. J. Anderson, "Fitting multivariate models to community data: a comment on distance-based redundancy analysis," Ecology, vol. 82, no. 1, pp. 290-297, 2001.
[35] M. J. Anderson, "A new method for non-parametric multivariate analysis of variance," Austral Ecology, vol. 26, no. 1, pp. 3246, 2001.

[36] K. R. Clarke, "Non-parametric multivariate analyses of changes in community structure," Australian Journal of Ecology, vol. 18, no. 1, pp. 117-143, 1993.

[37] K. R. Clarke and M. Ainsworth, "A method of linking multivariate community structure to environmental variables," Marine Ecology Progress Series, vol. 92, no. 3, pp. 205-219, 1993.

[38] K. R. Clarke, P. J. Somerfield, and M. G. Chapman, “On resemblance measures for ecological studies, including taxonomic dissimilarities and a zero-adjusted Bray-Curtis coefficient for denuded assemblages," Journal of Experimental Marine Biology and Ecology, vol. 330, no. 1, pp. 55-80, 2006.

[39] P. J. Somerfield, K. R. Clarke, and F. Olsgard, "A comparison of the power of categorical and correlational tests applied to community ecology data from gradient studies," Journal of Animal Ecology, vol. 71, no. 4, pp. 581-593, 2002.

[40] C. Y. Bartlett, C. Manua, J. Cinner et al., "Comparison of outcomes of permanently closed and periodically harvested coral reef reserves," Conservation Biology, vol. 23, no. 6, pp. 1475-1484, 2009.

[41] J. Cinner, M. J. Marnane, T. R. McClanahan, and G. R. Almany, "Periodic closures as adaptive coral reef management in the Indo-Pacific," Ecology and Society, vol. 11, no. 1, article 31, 2006.

[42] S. Jennings, S. P. R. Greenstreet, and J. D. Reynolds, "Structural change in an exploited fish community: a consequence of differential fishing effects on species with contrasting life histories," Journal of Animal Ecology, vol. 68, no. 3, pp. 617627, 1999.

[43] M. D. Nicholson and S. Jennings, "Testing candidate indicators to support ecosystem-based management: the power of monitoring surveys to detect temporal trends in fish community metrics," ICES Journal of Marine Science, vol. 61, no. 1, pp. 3542, 2004

[44] Y. Letourneur, M. Kulbicki, and P. Labrosse, "Spatial structure of commercial reef fish communities along a terrestrial runoff gradient in the northern lagoon of New Caledonia," Environmental Biology of Fishes, vol. 51, no. 2, pp. 141-159, 1998.

[45] J. E. Cinner, M. J. Marnane, and T. R. McClanahan, "Conservation and community benefits from traditional coral reef management at Ahus Island, Papua New Guinea," Conservation Biology, vol. 19, pp. 1714-1723, 2005.

[46] S. A. Sandin, J. E. Smith, E. E. DeMartini et al., "Baselines and degradation of coral reefs in the Northern Line Islands," PLoS ONE, vol. 3, no. 2, article e1548, 2008.

[47] W. M. Hamner, M. S. Jones, J. H. Carleton, I. R. Hauri, and D. M. Williams, "Zooplankton, planktivorous fish, and water currents on a windward reef face: great Barrier Reef, Australia," Bulletin of Marine Science, vol. 42, no. 3, pp. 459-479, 1988.

[48] A. Green and D. R. Bellwood, "Monitoring functional groups of herbivorous reef fishes as indicators of coral reef resilience: a practical guide for coral reef managers in the Asia Pacific Region," in Proceedings of IUCN Working Group on Climate Change and Coral Reefs (IUCN '09), Gland, Switzerland, 2009.

[49] D. O. Obura and G. Grimsditch, "Resilience assessment of coral reefs_-assessment protocol for coral reefs, focusing on coral bleaching and thermal stress," in Proceedings of IUCN Working Group on Climate Change and Coral Reefs (IUCN '09), Gland, Switzerland, 2009. 
[50] S. D. Jupiter, T. Tui, S. Shah et al., "Integrating EBM science to assess marine protected area effectiveness: clues from coral proxies of land disturbance, ecological assessments and socioeconomic surveys," Tech. Rep. 02/10, Wildlife Conservation Society-Fiji, Suva, Fiji, 2010.

[51] A. Maurstad, "Fishing in murky waters-ethics and politics of research on fisher knowledge," Marine Policy, vol. 26, no. 3, pp. 159-166, 2002.

[52] G. R. Russ and A. C. Alcala, "Marine reserves: long-term protection is required for full recovery of predatory fish populations," Oecologia, vol. 138, no. 4, pp. 622-627, 2004.

[53] A. T. White, "The effect of community-managed marine reserves in the Philippines on their associated coral reef fish population," Asian Fisheries Science, vol. 2, pp. 27-41, 1988.

[54] T. R. McClanahan and B. Kaunda-Arara, "Fishery recovery in a coral-reef marine park and its effect on the adjacent fishery," Conservation Biology, vol. 10, no. 4, pp. 1187-1199, 1996.

[55] G. R. Russ and A. C. Alcala, "Marine reserves: rates and patterns of recovery and decline of large predatory fish," Ecological Applications, vol. 6, no. 3, pp. 947-961, 1996.

[56] R. Grober-Dunsmore, V. Bonito, W. Aalbersberg, A. Bogiva, and J. Comley, "Evaluation and enhancement of marine conservation efforts in Tikina Komave and Navosa Province: CPUE and fish tagging study," in Proceedings of the Inaugural Fiji Islands Conservation Science Forum, A. P. Jenkins, S. R. Prasad, J. Bacchiochi, P. A. Skelton, and N. Yakub, Eds., Wetlands International-Oceania, 2009.

[57] H. Seidel, Evaluating the Role of Science in Community Based Adaptive Management of Coastal Resources in Fiji, M.S. thesis, University of Bremen, Bremen, Germany, 2009.

[58] G. R. Russ and A. C. Alcala, "Marine reserves: rates and patterns of recovery and decline of predatory fish, 1983-2000," Ecological Applications, vol. 13, no. 6, pp. 1553-1565, 2003. 

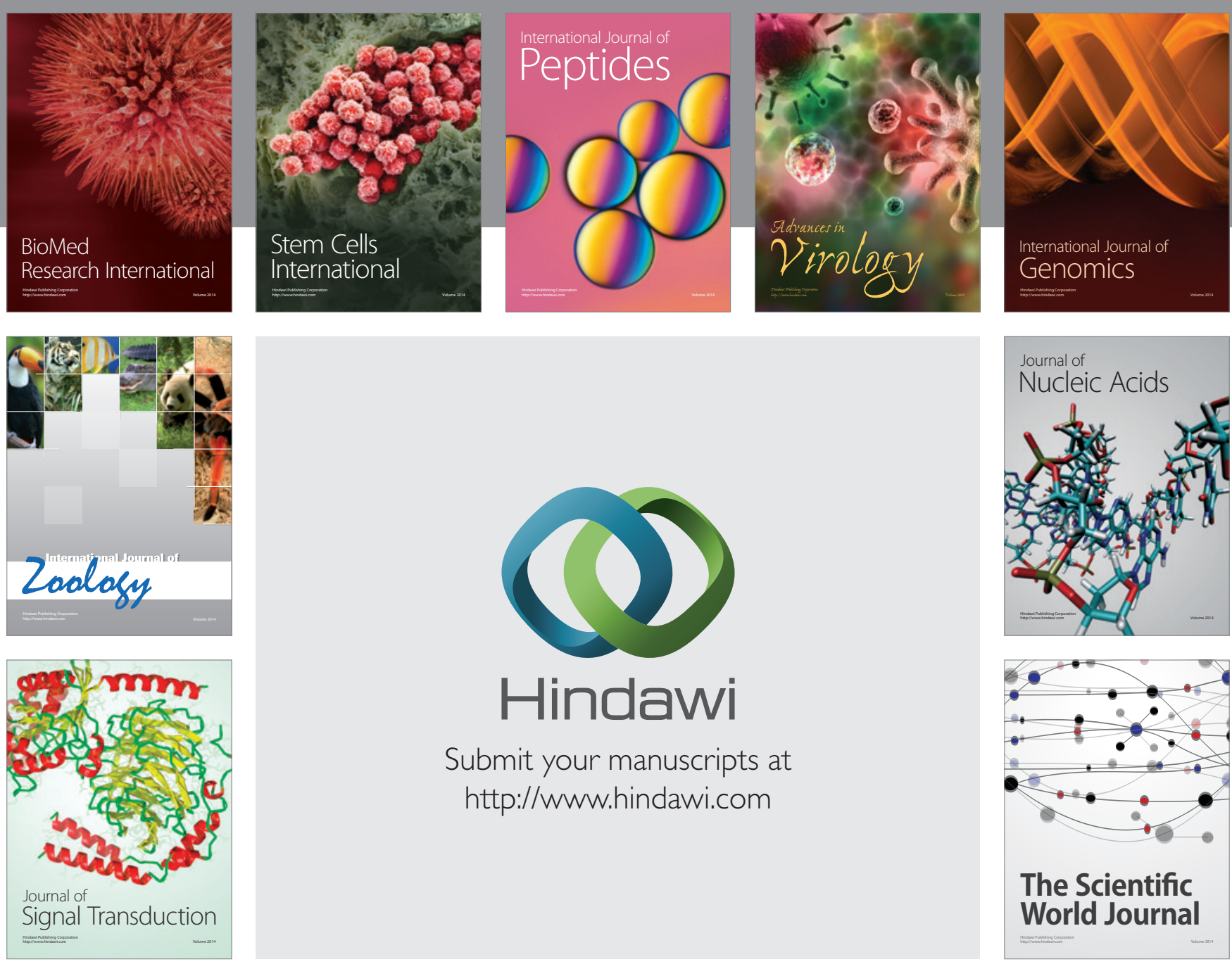

Submit your manuscripts at

http://www.hindawi.com
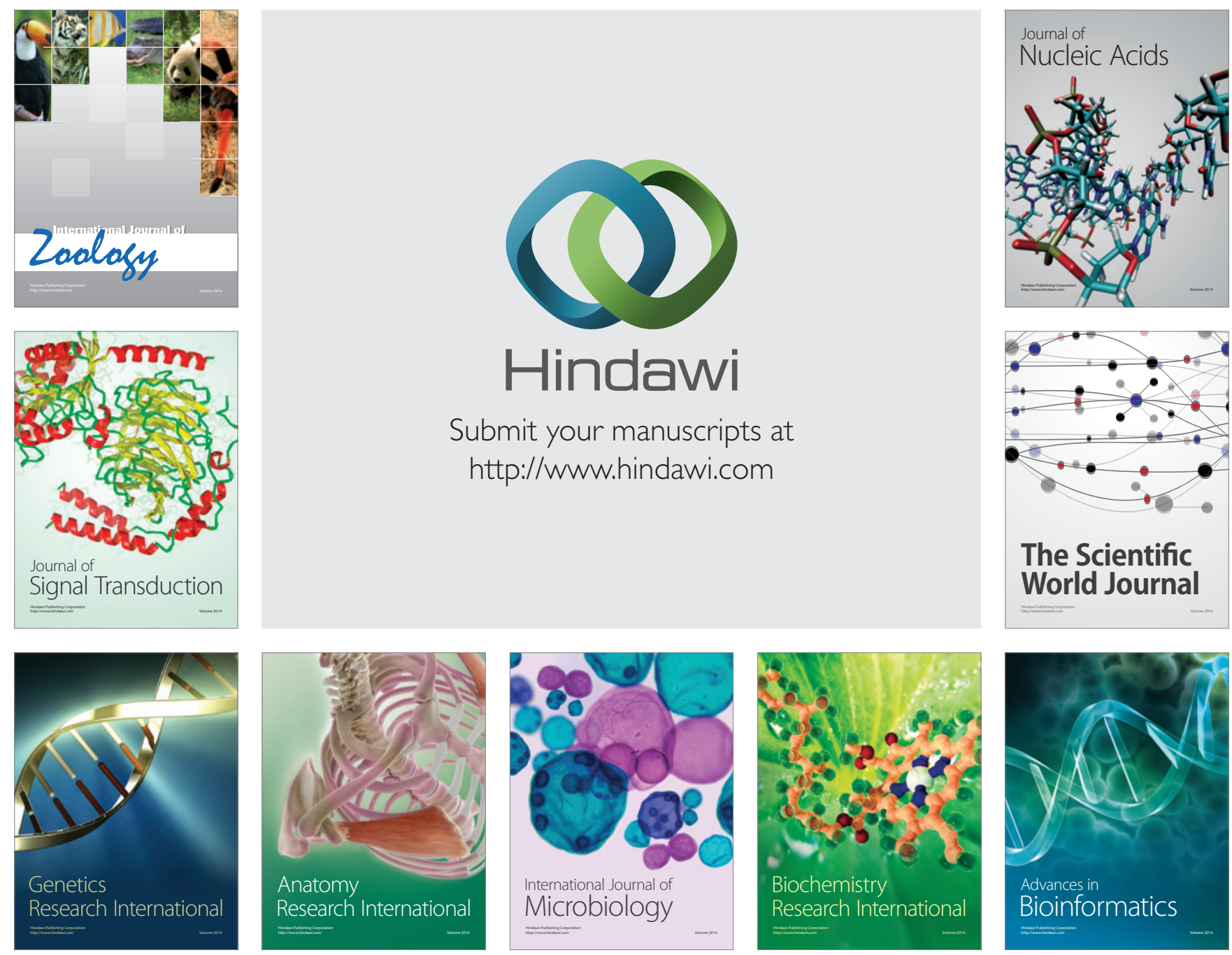

The Scientific World Journal
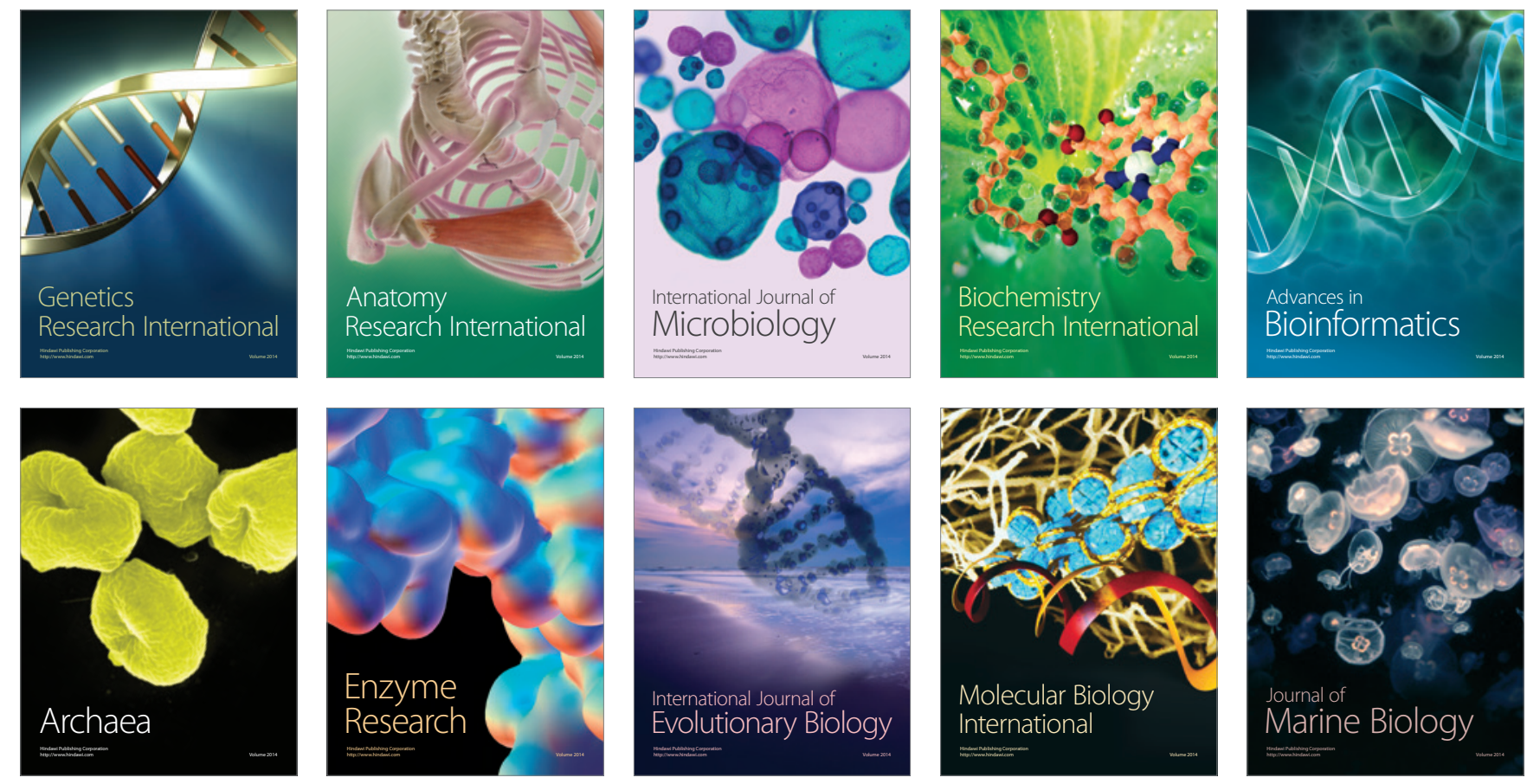